\title{
Study of the biological potential of in vitro extracts for Zeyheria tuberculosa (Bignoniaceae)
}

\author{
Isabelle Souza de Mélo Silva', Raíssa Fernanda Evangelista Pires dos Santo², Naélia Monique Moreira Brito Silva², \\ Andressa Leticia Lopes da Silva ${ }^{2}$, Ingridy Viana Lucena ${ }^{1 *}$, Andriele Mendonça Barbosa ${ }^{1}$, Klebson Silva Santos ${ }^{1}$, \\ Thiane de Vasconcellos Costa Melo², Genilson Sarmento Lins Júnior², Francine Ferreira Padilha', \\ Patricia de Albuquerque Sarmento ${ }^{2}$, Maria Lysete de Assis Bastos ${ }^{2}$
}

From 5th Congress of the Brazilian Biotechnology Society (SBBIOTEC)

Florianópolis, Brazil. 10-14 November 2013

\section{Background}

The indiscriminate use of antibiotics, associated with the emergence of microorganisms human resistant pathogens to major classes of antibiotics, has caused many clinical problems in the treatment of infectious diseases. Plants used in order to medicinal purpose for treatment, healing and/or prevention is one of the oldest forms of medicinal practice of humanity [1]. Biomonitored studies are developed and refined, relating popular knowledge to realization of bioassays that confirm the therapeutic efficacy and the low toxicity, as the plants with efficacy proven for a particular biological activity are possible raw materials for natural and/or synthetic medicines [2]. The aim of this study was to evaluate the antibacterial, cytotoxic and antioxidant potential in vitro of extracts of a native plant from Alagoas, the Zeyheria tuberculosa, known as Ipê Felpudo used in Brazilian folk medicine for the treatment of cancer and skin diseases [3].

\section{Methods}

In vitro experimental research, was realized in the Laboratory of Wound Care at Federal University of Alagoas. Four fractions were tested in different parts (leaves, stems) of Zeyheria tuberculosa, extracts $\mathrm{XL}_{1} . \mathrm{XL}_{2}, \mathrm{XL}_{3}$ and $\mathrm{XS}_{1}$. Antimicrobial activity was determined by microbial sensitivity tests, the method of well diffusion, plates-holes diffusion assay and broth microdilution method for determination of minimum inhibitory concentration (MIC). The bacterial inhibition percentage of disk diffusion test was calculated by dividing the mean of the sample inhibition, for hundred

'Instituto de Tecnologia e Pesquisa, Universidade Tiradentes, Av. Murilo Dantas, 300, Farolândia, Aracaju, Sergipe, CEP 49032-490, Brazil Full list of author information is available at the end of the article times by the mean of inhibition halos for the positive control[4]. Were used eight bacterial strains, among them Gram-positive and Gram-negative bacteria, distributed by American Type Cell Cellection. The evaluation of the samples toxicity was obtained through toxicity test with Brine Shrimp. The evaluation of the free radical sequester ability was performed according to the free radical sequester activity of the synthetic 2,2-Diphenyl-1-picrylhydrazyl (DPPH).

\section{Results and conclusions}

All tested samples showed moderately active against the strain of Sthapylococcus aureus (ATCC 25923) using the agar diffusion method by the well technique with percentage of inhibition $>25 \%$ and $<75 \%$. The $\mathrm{XS}_{1}$ extract showed the most significant antimicrobial activity in MIC, inhibiting the strain growth of $S$. aureus with 1000 until $125 \mu \mathrm{g} \mathrm{mL}^{-1}$ concentration. Identified the absence of toxicity in all samples, as the mortality percentage rate was $\leq 30 \%\left(\mathrm{CL}_{50} \geq 1000 \mu \mathrm{g} \mathrm{mL}^{-1}\right)$. In the antioxidant test, all samples were considered inactive with $\mathrm{CL}_{50}>200 \mathrm{mg} / \mathrm{mL}$. Phytochemical studies previously performed with $Z$. tuberculosa showed the presence of isolated flavonoids justifying the antimicrobial activity found [3]. These results represent the primary indications security plant species for performing in-vivo bioassays with perspective in the infection control.

\section{Acknowledgements}

Brazilian Ministry of Science and Technology, Federal University of Alagoas, Center for Information Technology (CIT-PROPEP), Research Laboratory of Wound Care, Laboratory of Biomaterials, Tiradentes University.

\section{Authors' details}

'Instituto de Tecnologia e Pesquisa, Universidade Tiradentes, Av. Murilo Dantas, 300, Farolândia, Aracaju, Sergipe, CEP 49032-490, Brazil. 'Laboratório 
Published: 1 October 2014

\section{References}

1. Veiga Junior VF, Pinto AC, Maciel MAM: Medicinal Plants: Safe Healing? New Chemistry 2005, 28(3).

2. Giulietti AM, Harley RM, Queiroz LP, Wanderley MG, Berg CVD: Biodiversity and conservation of plants in Brazil. Megadiversity 2005, 1(1):52-61.

3. Bastos ML, Lima MR, Conserva LM, Andrade VS, Rocha EM, Lemos RP. Studies on the antimicrobial activity and brine shrimp toxicity of Zeyheria tuberculosa (Vell.) Bur. (Bignoniaceae) extracts and their main constituents. Ann Clin Microbiol Antimicrob 2009, 8:16.

4. Déciga-Campos M, Rivero-Cruz I, Arriaga-Alba M, Castañeda-Corral G, Angeles-López GE: Acute toxicity and mutagenic activity of Mexican plants used in traditional medicine. J Ethnopharmacol 2007, 110:334-42.

doi:10.1186/1753-6561-8-S4-P13

Cite this article as: Silva et al: Study of the biological potential of in vitro extracts for Zeyheria tuberculosa (Bignoniaceae). BMC Proceedings 2014 8(Suppl 4):P13.

\section{Submit your next manuscript to BioMed Central} and take full advantage of:

- Convenient online submission

- Thorough peer review

- No space constraints or color figure charges

- Immediate publication on acceptance

- Inclusion in PubMed, CAS, Scopus and Google Scholar

- Research which is freely available for redistribution

Submit your manuscript at www.biomedcentral.com/submit 